\title{
Activity of the prophenoloxidase system and survival of triatomines infected with different Trypanosoma cruzi strains under different temperatures: understanding Chagas disease in the face of climate change
}

Berenice González-Rete ${ }^{1}$, Paz María Salazar-Schettino², Martha I. Bucio-Torres², Alex Córdoba-Aguilar ${ }^{3^{*}}$ and Margarita Cabrera-Bravo ${ }^{2^{*}}$

\begin{abstract}
Background: Little is known about how human disease vectors will modify their life history patterns and survival capacity as a result of climate change. One case is that of Chagas disease, which has triatomine bugs and Trypanosoma cruzi as vectors and parasite, respectively. This work aimed to determine: (i) the activity of the prophenoloxidase system (prophenoloxidase and phenoloxidase activity, two indicators of immune ability) in three intestine regions (anterior midgut, posterior midgutand rectum) of the triatomine bug Meccus pallidipennis under three temperature conditions $\left(20^{\circ} \mathrm{C}, 30^{\circ} \mathrm{C}\right.$ and $34^{\circ} \mathrm{C}$ ) against two T. cruzi strains [ITRI/MX/14/CHIL (Chilpancingo) and ITRI/MX/12/MOR (Morelos)], and (ii) whether vector survival varies under these three temperatures after infection by these T. cruzi strains.

Results: Our results indicate that prophenoloxidase activity was lower at higher temperatures, that the level of prophenoloxidase activity elicited by each strain was different (higher in Chilpancingo than in Morelos strains), and that prophenoloxidase activity was more intense in the anterior midgut than in the posterior midgut or rectum. Survival rates were lower in insects maintained at higher temperatures and infected by Chilpancingo strains.

Conclusions: These results indicate that climate change could lead to lower prophenoloxidase activity and survival rates in triatomines when infected with different T. cruzi strains, which could reduce the vector capacity of $M$. pallidipennis.
\end{abstract}

Keywords: Meccus pallidipennis, Trypanosoma cruzi, Strains, Climate change, Temperature, Phenoloxidase activity, Prophenoloxidase activity

\footnotetext{
*Correspondence: acordoba@iecologia.unam.mx; imay@unam.mx

2 Departamento de Microbiología y Parasitología, Facultad de Medicina,

Universidad Nacional Autónoma de México, Ciudad de México, Mexico

${ }^{3}$ Departamento de Ecología Evolutiva, Instituto de Ecología, Universidad

Nacional Autónoma de México, Apdo. P. 70-275, Circuito Exterior, Ciudad

Universitaria, Coyoacán, 04510 Ciudad de México, Mexico

Full list of author information is available at the end of the article
}

(c) The Author(s) 2019. This article is distributed under the terms of the Creative Commons Attribution 4.0 International License (http://creativecommons.org/licenses/by/4.0/), which permits unrestricted use, distribution, and reproduction in any medium, provided you give appropriate credit to the original author(s) and the source, provide a link to the Creative Commons license, and indicate if changes were made. The Creative Commons Public Domain Dedication waiver (http://creativecommons.org/ publicdomain/zero/1.0/) applies to the data made available in this article, unless otherwise stated. 


\section{Background}

The global temperature increase in recent decades has triggered a multitude of ecological changes, host-parasite interactions being one of such changes $[1,2]$. In this regard, understanding the interactions between vector insects and the pathogen agents that they transmit to humans is crucial in assessing the future risk posed by these diseases [3-5]. Recent projections indicate an increase in the distribution of vector insects and the prevalence of the diseases they transmit $[6,7]$, considering that insects are ectothermic (i.e. basic physiological functions such as locomotion, growth and reproduction are strongly influenced by environmental temperature) [8] and that higher temperatures will promote shorter life-cycles and more rapid reproduction [9, 10]. While this process cannot be generalized for all ectothermic organisms [11], not even for all vectors $[9,12]$, it is true that empirical data on insects under controlled conditions are much needed to support theoretical models [3, 13].

Triatomines (Hemiptera: Reduviidae) are vectors for Trypanosoma cruzi (Kinetoplastida) [14, 15], the causative agent of Chagas disease. In general, the geographical range of triatomines extends from tropical zones, where they withstand temperatures near $40{ }^{\circ} \mathrm{C}[16,17]$, to more temperate zones, with temperatures of about $18{ }^{\circ} \mathrm{C}[18$, 19]. However, the relationship between T. cruzi and its vectors could modulate these temperature thresholds $[20,21]$, possibly due to resource cost-related factors and manipulation by the parasite [22].

In vitro studies on triatomines have demonstrated that higher temperatures lead to increased development and reproduction rates for the vector [23, 24], and more frequent feeding events [25-28]. Such an increase would result in a higher risk of $T$. cruzi transmission [28-30], but a balance could be established due to a possible decrease in triatomine survival [26, 31-33]. It is not clear whether this decrease in survival rate is due to an interaction with the parasite, since higher temperatures are expected to favor a more robust prophenoloxidase activity (a proxy of the insect's immune response) in the vector $[28,34-36]$.

Triatomine-T. cruzi interactions take place in the digestive tract of the vector [37-39]. When triatomines feed from the blood of an infected vertebrate, T. cruzi colonize the anterior midgut (AMG), posterior midgut (PMG) and rectum $[39,40]$.

Interestingly, the AMG is a battlefield between parasites and the host, since almost immediately after blood ingestion, about $80 \%$ of parasites die $[41,42]$. The prophenoloxidase (proPO) and phenoloxidase (PO) enzymatic cascade is known to be a key element in the immune response associated to the defense against pathogens and their removal [43-46]. In this regard, proPO and PO activity in $M$. pallidipennis were found associated after one week of infection with T. cruzi [45].

This study aimed to determine the effect of temperature on the immune response in triatomine-T. cruzi interactions, as assessed by proPO and PO activity, in the AMG, PMG and rectum of $M$. pallidipennis. This species is the vector with the highest epidemiological importance in the transmission of Chagas disease in Mexico [47]. It can survive in a temperature range of $18-28{ }^{\circ} \mathrm{C}$ when infected by $T$. cruzi, with $27-28{ }^{\circ} \mathrm{C}$ being its optimal range $[48,49]$. Considering these temperature ranges, triatomine vectors in our study were bred and kept at $20^{\circ} \mathrm{C}$, $30{ }^{\circ} \mathrm{C}$ and $34{ }^{\circ} \mathrm{C}$. The reason for choosing the last temperature was two-fold: first, some climate change scenarios predict an increase of $4{ }^{\circ} \mathrm{C}$ above the current temperatures [50]; secondly, previous experiments have indicated that $M$. pallidipennis does not survive above $34{ }^{\circ} \mathrm{C}$. As an additional variable, infection with two $T$. cruzi strains was considered in this work. Different isolates and discrete typing units (DTUs) are known to occur in different regions under natural conditions, but it is not clear whether they affect the vector fitness in a differential manner. Increased temperatures are expected to improve triatomine proPO activity [51,52] at the AMG level, while vector survival rates are expected to decrease [21]. The effect of the different isolates cannot be predicted, but the effects of an isolate type on triatomine survival are expected to remain unaltered under different temperature conditions.

\section{Methods}

\section{Meccus pallidipennis specimens}

Newly-moulted, fifth-instar $M$. pallidipennis nymphs were kept in the insectarium of the Laboratorio de Biología de Parásitos (Parasite Biology Laboratory, Department of Microbiology and Parasitology, Faculty of Medicine, Universidad Nacional Autónoma de México) at $30{ }^{\circ} \mathrm{C}$ and a relative humidity $(\mathrm{RH})$ of $60 \%$ under a $12 / 12$ $\mathrm{h}$ light/darkness cycle. These triatomines are descendant of insects collected in the state of Morelos, Mexico, in 1989, with regular introduction of wild specimens. Specimens were randomly selected for the experiments.

\section{Trypanosoma cruzi strains}

The strain ITRI/MX/12/MOR (further referred to as Morelos) was obtained from a male $M$. pallidipennis specimen captured and isolated in 2012 in Cuernavaca, Morelos, Mexico. This strain has been characterized as TcI [45]. The strain ITRI/MX/14/CHIL (further referred to as Chilpancingo) was obtained from a female $M$. pallidipennis specimen captured and isolated in 2014 in Chilpancingo, Guerrero, Mexico. This strain has not 
yet been characterized. Both strains were used to infect female CD-1 mice (15-18 g). Both strains were maintained in $\mathrm{CD}-1$ mice by cyclical passages.

\section{Infection, incubation and confirmation of infection Infection of M. pallidipennis nymphs}

For each strain, 150 nymphs were infected by allowing them to feed from mice that had been inoculated with 20,000 T. cruzi metacyclic trypomastigotes/ml 15 days before, to ensure that the parasite was in the exponential stage of growth [45]. Additionally, 150 nymphs were allowed to feed from non-infected female CD-1 mice of the same weight (15-18 g), to be used as a control group. The nymphs of each group were allowed to feed for 15-20 min in the dark, in groups of 5 nymphs per mouse (Morelos, Chilpancingo and control) until they detached themselves from the feeding source and showed clear signs of satiety (the abdomen grew to approximately the double of its pre-feeding size). Based on the levels of parasitemia in the mice, each infected insect ingested approximately 8000 parasites.

\section{Temperature challenge}

After feeding, the nymphs were placed in plastic jars (one per jar) and labeled for identification. Fifty nymphs infected with the Morelos strain, 50 nymphs infected with the Chilpancingo strain, and 50 control (noninfected) nymphs were incubated at $20 \pm 2{ }^{\circ} \mathrm{C}, 30 \pm 2{ }^{\circ} \mathrm{C}$ and $34 \pm 2{ }^{\circ} \mathrm{C}$ and $60 \% \mathrm{RH}$ for 15 days (acclimatization period) in an incubator (FE-131AD, FELISA, City, Mexico). In total, 150 nymphs were subjected to each temperature.

\section{Confirmation of infection}

After 15 days of incubation, the rectal content of each specimen was obtained by abdominal compression and examined by direct observation to confirm the presence of T. cruzi blood trypomastigotes [45]. A drop of PBS $1 \times \mathrm{pH} 7.2\left(\mathrm{Na}_{2} \mathrm{HPO}_{4} 8 \times 10^{-6} \mathrm{M}, \mathrm{KH}_{2} \mathrm{PO}_{4} 10^{-6} \mathrm{M}, \mathrm{KCl}\right.$ $3 \times 10^{-6} \mathrm{M}, \mathrm{NaCl} 10^{-4} \mathrm{M}$ ) was placed on a glass slide. A drop of triatomine rectal content was added and the mixture was homogenized [45]. A 10- $\mu$ l aliquot was taken and microscopically observed under a $40 \times$ objective (Olympus CH-2, Center Valley, PA, USA).

\section{Extraction of the $A M G, P M G$ and rectum}

After the infection was confirmed, the insects were dissected under a stereoscopic microscope (Stemi 2000, Carl Zeiss, Jena, Germany). The legs were removed with dissecting forceps and the insect was placed in a Petri dish at $4{ }^{\circ} \mathrm{C}$. The abdomen was disinfected with $70 \%$ alcohol. The connexivum was identified and sectioned to expose the abdominal cavity. Malpighian tubules and the fat body were removed [45]. The digestive system was identified [39], and the AMG, PMG and rectum were dissected. Each region of the triatomine digestive system was separately placed in a 1.5-ml Eppendorf tube with $200 \mu \mathrm{l}$ of sterile PBS $1 \times \mathrm{pH} 7.2$.

\section{Processing the $A M G, P M G$ and rectum from infected and non-infected nymphs}

The AMG, PMG and rectum from infected and control nymphs were dissected and placed separately in sterile PBS as described above and washed to remove any residue of vertebrate undigested blood. The supernatant was discarded and $200 \mu \mathrm{l}$ of ice-cold, sterile PBS $1 \times \mathrm{pH} 7.2$ were added. The tissue was macerated with a pestle to completely disaggregate it and it was then centrifuged in an Allegra 64R microcentrifuge (Beckman Coulter, Brea, CA, USA) at $9168 \times g$ for $10 \mathrm{~min}$ at $4{ }^{\circ} \mathrm{C}$. Then, $20 \mu \mathrm{l}$ of supernatant were taken and placed in $180 \mu$ of ice-cold, sterile PBS $1 \times \mathrm{pH} 7.2$ (diluted 1:10) [53]. The tubes were kept on ice until used.

\section{proPO and $P O$ activity in triatomine $A M G, P M G$ and rectum} proPO and PO activity in triatomine AMG, PMG and rectum were spectrophotometrically determined [43, 54]. Briefly, $25 \mu \mathrm{l}$ each of AMG, PMG or rectum supernatant from each nymph was placed on a 96-well microplate (Costar 96, Corning, NY, USA). To determine proPO activity, $10 \mu \mathrm{l}$ of sterile PBS $1 \times \mathrm{pH} 7.2$ and $5 \mu \mathrm{l}$ of bovine $\alpha$-chymotrypsin $(1 \mathrm{mg} / \mathrm{ml}$; Sigma-Aldrich, Saint Louis, MO, USA) were added. The microplate was incubated at $37{ }^{\circ} \mathrm{C}$ for $1 \mathrm{~h}$ in the dark. Then, $25 \mu \mathrm{l}$ of L-DOPA $(4 \mathrm{mg} /$ $\mathrm{ml}$, Sigma-Aldrich) was added and the plate was incubated at $37^{\circ} \mathrm{C}$ for $1 \mathrm{~h}$ in the dark $[45,55]$. A blank containing 35 $\mu \mathrm{l}$ of sterile PBS $1 \times \mathrm{pH} 7.2$ and $5 \mu \mathrm{l}$ of $\alpha$-chymotrypsin was included. All samples were analyzed in duplicate.

To determine PO activity, $25 \mu \mathrm{l}$ each of AMG, PMG and rectum supernatant from each nymph was placed on a 96-well microplate (Costar 96). Ten microliters of sterile PBS $1 \times$ pH 7.2 and $25 \mu \mathrm{l}$ of L-DOPA ( $4 \mathrm{mg} / \mathrm{ml}$, Sigma) were added. The plate was incubated at $37^{\circ} \mathrm{C}$ for $3 \mathrm{~h}$ in the dark [45,56]. A blank containing $5 \mu$ of sterile PBS $1 \times \mathrm{pH}$ 7.2 and $5 \mu \mathrm{l}$ of $\alpha$-chymotrypsin was included. All samples were analyzed in duplicate.

To determine proPO and $\mathrm{PO}$ activity, the absorbance of each sample was read in the spectrophotometer at $490 \mathrm{~nm}$ every $5 \mathrm{~min}$ for $1 \mathrm{~h}$. Enzyme activity was determined by calculating the slope of an absorbance-time plot [45] and using the following equation:

$$
\text { Enzyme activity }=\frac{m\left(\frac{A b s}{\min }\right) * v f(L) * F}{\varepsilon\left(M^{-1} c m^{-1}\right) * b(c m)}
$$


where $\mathrm{m}$ is the slope of the Abs-time $\left(\mathrm{min}^{-1}\right)$ plot, $v f$ is the final volume of the reaction $(\mathrm{L}), F$ is the dilution factor, $\varepsilon$ is the molar extinction coefficient of dopachrome at $490 \mathrm{~nm}\left(3.715 \mathrm{M}^{-1} \mathrm{~cm}^{-1}\right)$ [54], and $b$ is the optical length $(0.5 \mathrm{~cm})$.

\section{Triatomine nymph survival Incubating M. pallidipennis nymphs}

One-hundred and eighty nymphs (120 infected and 60 non-infected) were incubated as mentioned above. Twenty nymphs infected with the Morelos strain, 20 infected with the Chilpancingo strain and 20 noninfected (controls) were incubated at $20 \pm 2{ }^{\circ} \mathrm{C}$. Sixty nymphs were incubated at $30 \pm 2{ }^{\circ} \mathrm{C}$, and 60 were incubated at $34 \pm 2{ }^{\circ} \mathrm{C}$. Then, all nymphs were monitored daily to determine survival, from infection time to death. An insect was regarded as dead when it failed to move any appendage after being manipulated with dissecting forceps for $1 \mathrm{~min}$.

\section{Statistical analysis}

The Kolmogorov-Smirnoff (K-S) test was used to determine data normality and variance heterogeneity, which indicated a normal distribution of data. Differences in nymph immunocompetent capacity between treatments were assessed by a univariate general linear model, having proPO and $\mathrm{PO}$ activity as dependent variables, while infection status (Morelos, Chilpancingo and control), intestine region (AMG, PMG and rectum) and incubation temperature $\left(20{ }^{\circ} \mathrm{C}, 30{ }^{\circ} \mathrm{C}\right.$ and $\left.34{ }^{\circ} \mathrm{C}\right)$ were predictive variables. The significance of the whole model, of each separate predictive variable, and of the interactions between infection status with intestine region and temperature was determined. The latter interaction was studied by comparing groups with $95 \%$ confidence intervals. This analysis was performed with the software SPSS v.24.0. All data are expressed as mean enzyme activity \pm standard error.

The Mantel-Cox log-rank test was used to determine the effect of infection status (Chilpancingo, Morelos or control) and temperature $\left(20^{\circ} \mathrm{C}, 30^{\circ} \mathrm{C}\right.$ or $\left.34{ }^{\circ} \mathrm{C}\right)$ on nymph survival time. Intergroup differences were determined with the Chi-square test between infected and non-infected groups, and between infected groups. This analysis was performed with the software GraphPad v.7.0.

\section{Results}

proPO activity with respect to infection status, temperature and intestine region

Significant differences were observed in the linear model with respect to infection status (Chilpancingo, Morelos and control), incubation temperature $\left(20^{\circ} \mathrm{C}, 30{ }^{\circ} \mathrm{C}\right.$ and $34{ }^{\circ} \mathrm{C}$ ) and intestine region (AMG, PMG and rectum; Table 1). Interactions between all predictive variables were also significant (Table 1).

In general, as temperature increased, proPO activity decreased (Fig. 1). Infection status also affected proPO activity, with the highest activity rate being observed in the Chilpancingo group, and the lowest in the controls (Fig. 2). The intestine region was also a good predictor of proPO, where the AMG yielded higher activity levels than the PMG and rectum, with no significant differences between the latter groups (Fig. 3). Since the AMG is the site with a significantly higher proPO expression, and no differences were observed between

Table 1 Parameters of the general linear univariate model of proPO activity with respect to infection status (infected by Chilpancingo strain, Morelos strain or control), temperature $\left(20^{\circ} \mathrm{C}, 30^{\circ} \mathrm{C}\right.$ and $34^{\circ} \mathrm{C}$ ), and intestine region (AMG, PMG and rectum), and their interactions

\begin{tabular}{|c|c|c|c|c|c|}
\hline Origin & Type-III SS & $d f$ & MS & F-value & $P$-value \\
\hline Corrected model & 2198.229 & 26 & 84.547 & 237.914 & 0.0001 \\
\hline Intersection & 1034.247 & 1 & 1034.247 & 2910.346 & 0.0001 \\
\hline Infection status & 98.982 & 2 & 49.491 & 139.266 & 0.0001 \\
\hline Temperature & 44.152 & 2 & 22.076 & 62.122 & 0.0001 \\
\hline Region & 1737.878 & 2 & 868.939 & 2445.174 & 0.0001 \\
\hline Status $\times$ temperature & 14.070 & 4 & 3.518 & 9.898 & 0.0001 \\
\hline Status $\times$ region & 195.991 & 4 & 48.998 & 137.879 & 0.0001 \\
\hline Temperature $\times$ region & 79.567 & 4 & 19.892 & 55.975 & 0.0001 \\
\hline Status $\times$ temperature $\times$ region & 27.589 & 8 & 3.449 & 9.704 & 0.0001 \\
\hline Error & 470.153 & 1323 & 0.355 & & \\
\hline Total & 3702.629 & 1350 & & & \\
\hline Corrected total & 2668.382 & 1349 & & & \\
\hline
\end{tabular}




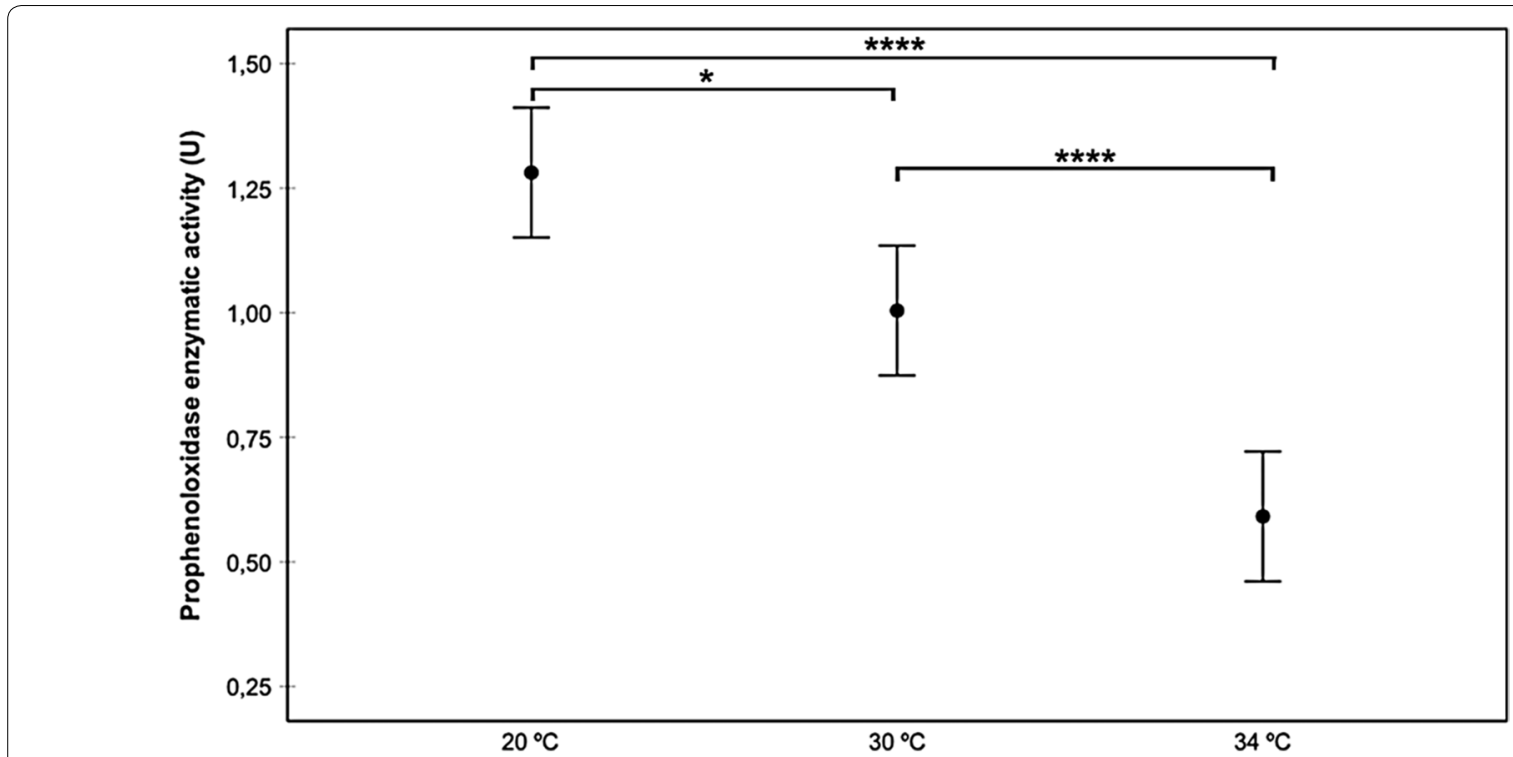

Fig. 1 Prophenoloxidase enzyme activity (proPO) in M. pallidipennis fifth-instar nymphs kept at three different temperatures $\left(20^{\circ} \mathrm{C}, 30^{\circ} \mathrm{C}\right.$ and $34^{\circ} \mathrm{C}$ ). ${ }^{*} P<0.05$, **** $P<0.0001$

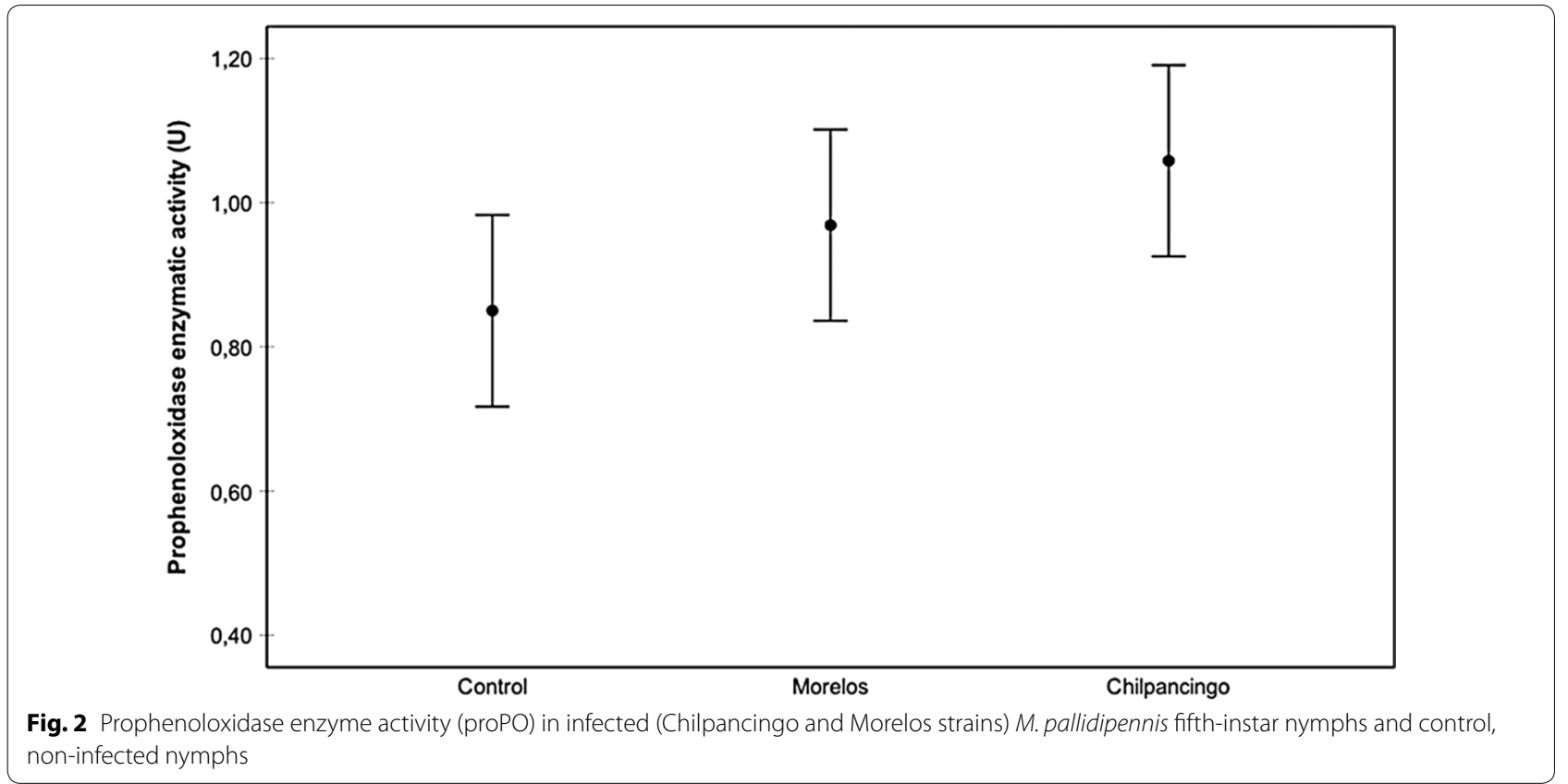

the PMG and rectum, only the AMG will be used in the following comparisons. proPO activity was higher in the Chilpancingo group than in the Morelos and control groups at $20^{\circ} \mathrm{C}$, but these differences were not observed at 30 and $34{ }^{\circ} \mathrm{C}$, which showed a reverse pattern with respect to $20^{\circ} \mathrm{C}$ (Fig. 4).
PO activity with respect to infection status, temperature and intestine region

Significant differences were found with respect to infection status, incubation temperature and intestine region (Table 2). Interactions between all predictive variables were also significant (Table 2). 


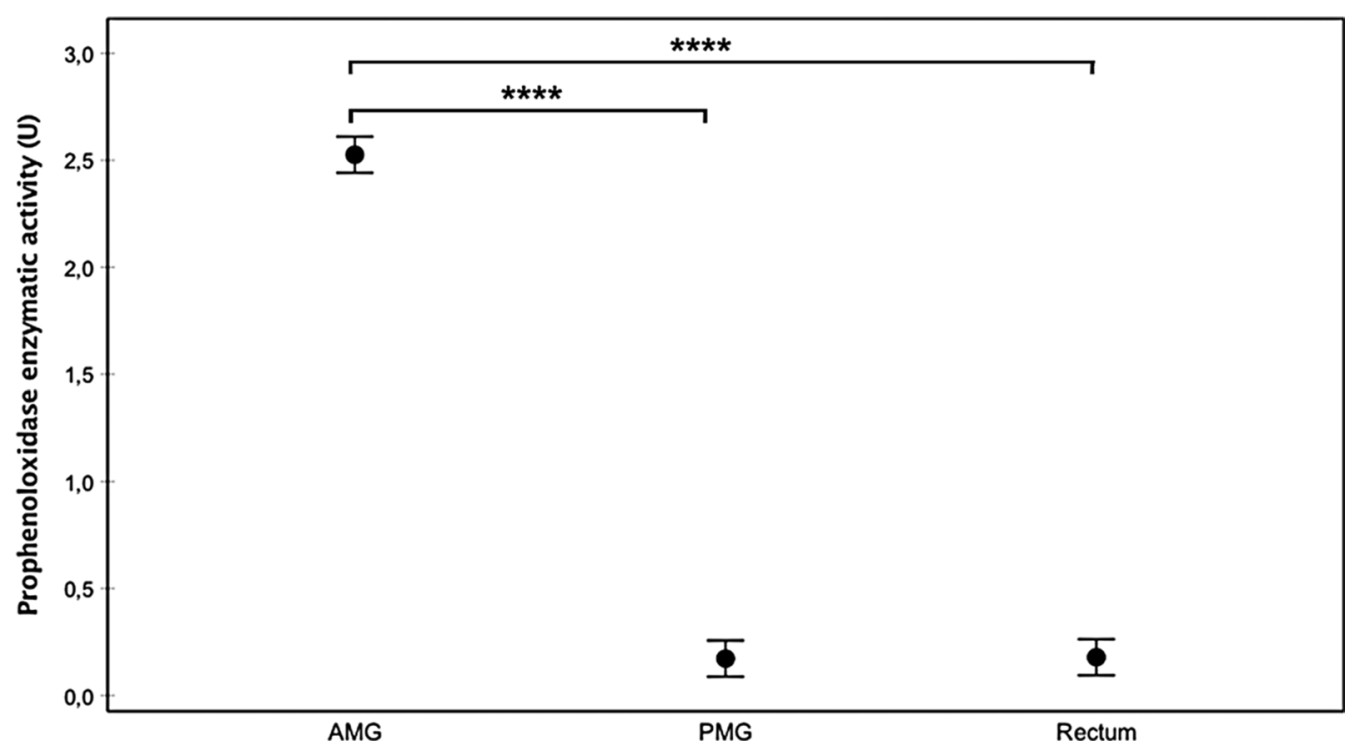

Fig. 3 Prophenoloxidase enzyme activity (proPO) in different regions (AMG, PMG and rectum) of the digestive system of M. pallidipennis fifth-instar nymphs. ${ }^{* * * *} P<0.0001$

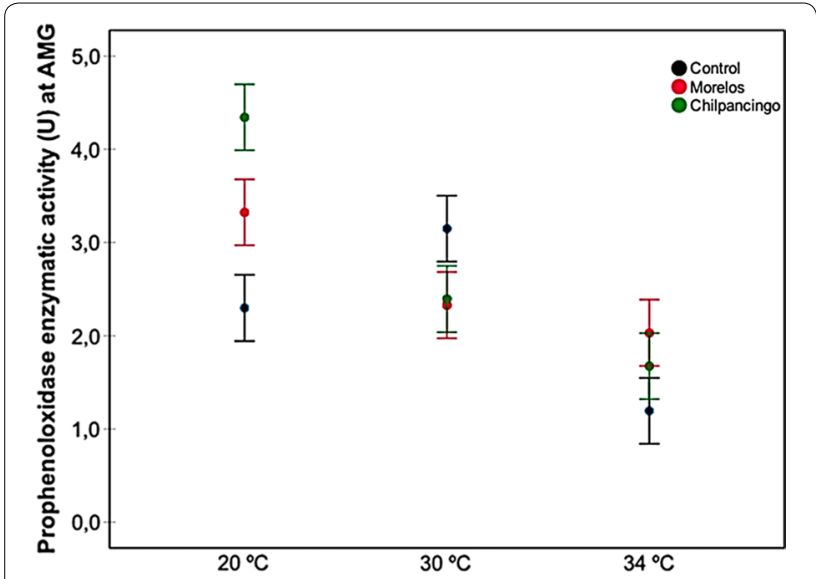

Fig. 4 Prophenoloxidase enzyme activity (proPO) in the AMG from infected M. pallidipennis fifth-instar nymphs (Chilpancingo and Morelos strains) and control, non-infected nymphs, at different temperatures $\left(20^{\circ} \mathrm{C}, 30^{\circ} \mathrm{C}\right.$ and $\left.34^{\circ} \mathrm{C}\right)$

The highest $\mathrm{PO}$ activity values were observed at $30{ }^{\circ} \mathrm{C}$ and were significantly lower at $34{ }^{\circ} \mathrm{C}$ (Fig. 5). With respect to infection status, the Chilpancingo group showed the highest PO activity, and control showed the lowest (Fig. 6). With respect to intestine region, the AMG yielded the highest response, with no differences between the PMG and rectum (Fig. 7). As with proPO, PO activity levels in the AMG will be used in the following comparisons, since no differences between the PMG and rectum groups were observed. PO activity was higher in the Chilpancingo group than in the Morelos and control groups at $20^{\circ} \mathrm{C}$, but these differences were not observed at 30 or $34^{\circ} \mathrm{C}$ (Fig. 8). Note that while the Chilpancingo group showed higher $\mathrm{PO}$ activity than the Morelos group at $20^{\circ} \mathrm{C}$, this pattern was opposite at 30 and $34{ }^{\circ} \mathrm{C}$.

\section{Effect of temperature on survival of fifth-instar $M$. pallidipennis nymphs}

In general, increased temperatures reduced triatomine lifespan (Fig. 9; Table 3). Infection status had some effect as well, decreasing insect survival. The Morelos strain had a higher effect on nymph survival than the Chilpancingo strain at $20^{\circ} \mathrm{C}$, but this effect was inverted at $34{ }^{\circ} \mathrm{C}$ (Figs. 9, 10).

\section{Discussion}

The immune capacity of triatomines against infection by $T$. cruzi was enhanced when the temperature was increased from $20{ }^{\circ} \mathrm{C}$ to $30{ }^{\circ} \mathrm{C}$, but this pattern changed dramatically at $34^{\circ} \mathrm{C}$. Our results, indicating a more efficient prophenoloxidase activity before a subtle increase in temperatures, are in agreement with reports on other insects [57]. This could be explained as the result of a better prophenoloxidase activity via phenotypic plasticity at moderately higher temperatures, which become inviable as temperature reaches a lethal threshold. In terms of defense against a pathogen, a temperature close to lethal levels could preclude the action of the triatomine prophenoloxidase activity against an infection, which is consistent with our results on nymph survival. Conversely, the insect may respond in the form of fever during infection, which may help them to fight off T. cruzi 
Table 2 Parameters of the general linear univariate model of PO activity with respect to infection status (infected by Chilpancingo strain, Morelos strain or control), temperature $\left(20^{\circ}, 30^{\circ}\right.$ and $\left.34^{\circ} \mathrm{C}\right)$, and intestine region (AMG, PMG and rectum), and their interactions

\begin{tabular}{|c|c|c|c|c|c|}
\hline Origin & Type-III SS & $d f$ & MS & F-value & $P$-value \\
\hline Corrected model & 2022.799 & 26 & 77.800 & 135.060 & 0.0001 \\
\hline Intersection & 1240.545 & 1 & 1240.545 & 2153.567 & 0.0001 \\
\hline Infection status & 9.933 & 2 & 4.967 & 8.622 & 0.0001 \\
\hline Temperature & 108.867 & 2 & 54.434 & 94.496 & 0.0001 \\
\hline Region & 1658.061 & 2 & 829.031 & 1439.184 & 0.0001 \\
\hline Status $\times$ temperature & 44.143 & 4 & 11.036 & 19.158 & 0.0001 \\
\hline Status $\times$ region & 16.534 & 4 & 4.133 & 7.176 & 0.0001 \\
\hline Temperature $\times$ region & 112.613 & 4 & 28.153 & 48.874 & 0.0001 \\
\hline Status $\times$ temperature $\times$ region & 72.647 & 8 & 9.081 & 15.764 & 0.0001 \\
\hline Error & 762.104 & 1323 & 0.576 & & \\
\hline Total & 4025.448 & 1350 & & & \\
\hline Corrected total & 2784.903 & 1349 & & & \\
\hline
\end{tabular}

Abbreviations: df, degrees of freedom; MS, mean square; SS, sum of squares

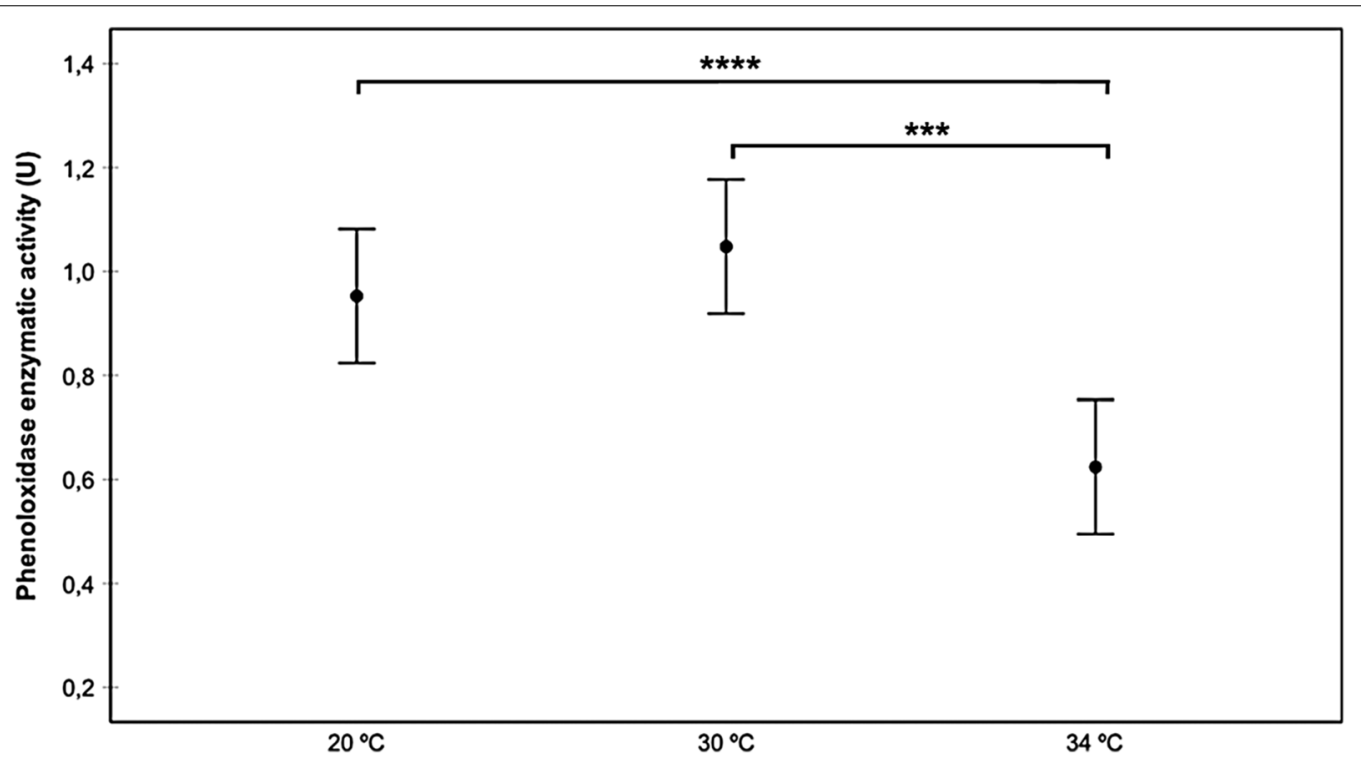

Fig. 5 Phenoloxidase enzyme activity $(P O)$ in M. pallidipennis fifth-instar nymphs kept at three different temperatures $\left(20^{\circ} \mathrm{C}, 30^{\circ} \mathrm{C}\right.$ and $\left.34^{\circ} \mathrm{C}\right)$. ${ }^{* *} P<0.0005$, ${ }^{* * *} P<0.0001$

[58]. If this were the case, however, one would expect that a high temperature may help insects to produce such an antiparasitic effect, but it is not the case as survival was lower as temperature rose. It is worth noting, however, that despite the strong effect of higher temperatures on reduced survival, this does not mean that the triatomine bugs do not rely on a fever response to deal with pathogens. Actually, other studies have found that triatomines show fever responses when sick [34]. It would be interesting to see whether $M$. pallidipennis bugs increase their fitness when allowed to choose ambient temperatures while facing different $T$. cruzi isolates.
The prophenoloxidase activity against $T$. cruzi in triatomines is known to be closely related with the intestinal tract [45]. Since the AMG is the anatomic region first colonized by the parasite and where its reproduction in the vector begins (and to a lesser extent in the PMG $[41,42])$, the prophenoloxidase activity in this region is expected to be more robust, as our results indicate. This is consistent with the massive death of the parasite observed within a few hours of infection [42], although it is not clear why the prophenoloxidase activity is not high enough in other gut regions to complete parasite removal. A possible explanation is that the cost of 

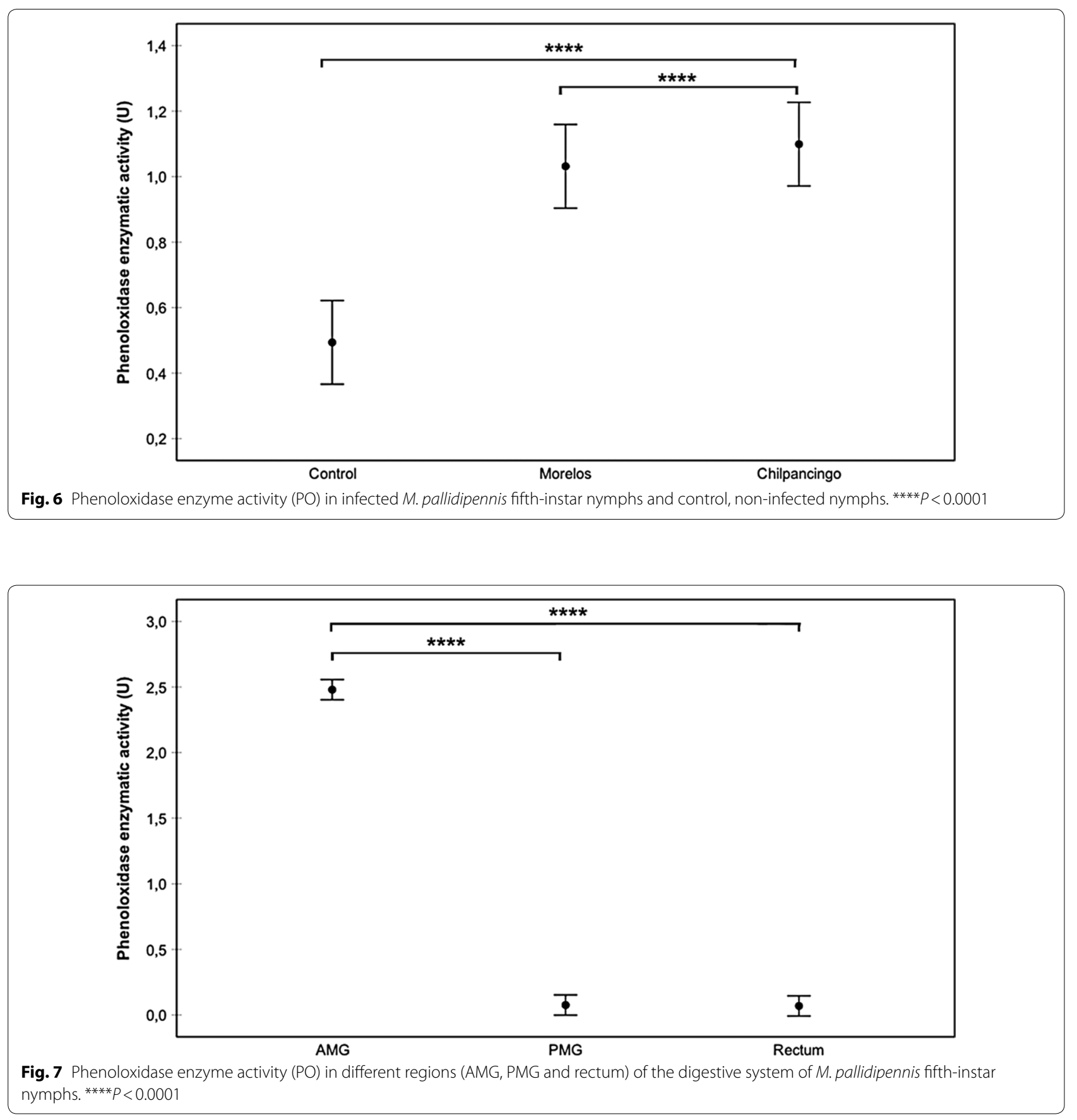

infection can affect AMG only, where parasite replication and resource sequestering could be considerably higher. Alternatively, it could be energetically prohibitive for the triatomine to maintain a high prophenoloxidase activity to kill the few surviving parasites. Such a tolerance would imply that relatively low parasite levels would be more preferable for the insect than complete removal $[59,60]$.

In contrast with the prophenoloxidase activity, our expectations with respect to survival were fulfilled. The negative effects of the parasite on triatomine fitness are not new. For instance, Botto-Mahan [61] found that T. cruzi infection delays the development and reduces survival rates in the triatomine Mepraia spinolai. Studies more closely related to our work found that $T$. cruzi reduced the survival of the triatomine Rhodnius prolixus, but only at $20{ }^{\circ} \mathrm{C}$ and $30{ }^{\circ} \mathrm{C}$ [31, 34]. In our case, the insects were more affected by the Chilpancingo strain than by the Morelos strain. These effects on survival are 


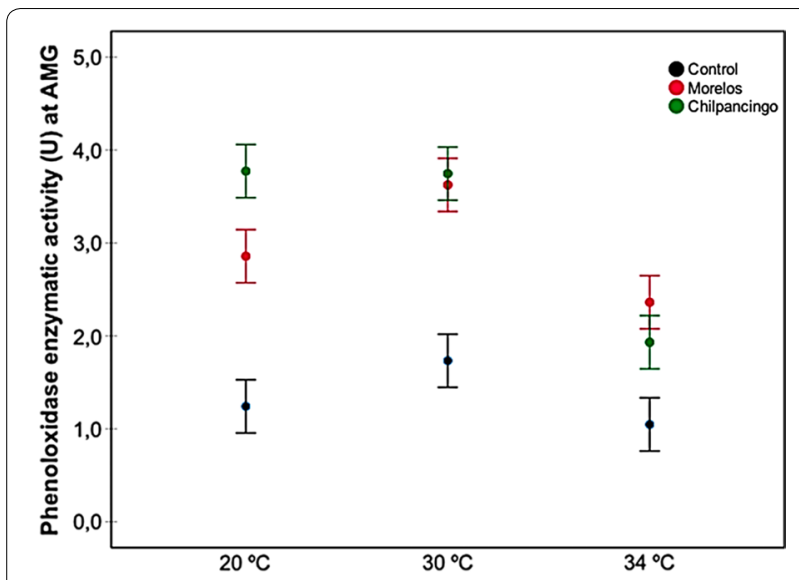

Fig. 8 Phenoloxidase enzyme activity (PO) in the AMG from infected M. pallidipennis fifth-instar nymphs and control, non-infected nymphs, at different temperatures $\left(20^{\circ} \mathrm{C}, 30^{\circ} \mathrm{C}\right.$ and $\left.34^{\circ} \mathrm{C}\right)$. Note that infected nymphs showed a higher activity than control specimens, irrespective of the temperature they were exposed to

related to those on the prophenoloxidase activity, suggesting that the vector allocates more resources to defend itself from a more dangerous pathogen. The more rapid death in insects infected with the Chilpancingo strain could be because this strain extracted more resources from the insect than the Morelos strain, but the precise mechanisms underlying infection costs in triatomines are still unknown [21]. Interestingly, the lethal effects of the Chilpancingo strain are even more perceptible at higher temperatures $\left(34^{\circ} \mathrm{C}\right)$. On one hand, these results do not agree with the report by Elliot et al. [31], who did not find a negative effect of high temperatures on $R$. prolixus survival. However, much lower temperatures $\left(30{ }^{\circ} \mathrm{C}\right)$ were used in those experiments than in our work $\left(34^{\circ} \mathrm{C}\right)$. It is possible that our temperature was closer to the lethal threshold for M. pallidipennis than the one used by Elliot et al. [31] for $R$. prolixus. On the other hand, our results may help us to understand the adaptation of triatomines to thermal thresholds in nature. For instance, it has been reported that the optimal temperature is $30{ }^{\circ} \mathrm{C}$ and the upper thermal limit for $M$. pallidipennis rarely seems to exceed $34{ }^{\circ} \mathrm{C}[48,49]$, which is in agreement with our results. While temperature levels in our study were selected based on the thresholds predicted by different climate change scenarios, it is likely that these scenarios are already occurring in some torrid areas of Mexico inhabited by M. pallidipennis [62].

Table 3 Survival of M. pallidipennis nymphs with respect to infection status (Chilpancingo strain, Morelos or control) and maintained at different temperatures

\begin{tabular}{llll}
\hline Temperature $\left({ }^{\circ} \mathrm{C}\right)$ & Status & Sample size $(n)$ & $\begin{array}{l}\text { Mean } \\
\text { survival } \\
\text { (days) }\end{array}$ \\
\hline 20 & Control & 20 & 166 \\
& Morelos & 20 & 102 \\
30 & Chilpancingo & 20 & 112 \\
& Control & 20 & 117 \\
\multirow{3}{*}{34} & Morelos & 20 & 80 \\
& Chilpancingo & 20 & 80 \\
& Control & 20 & 90 \\
& Morelos & 20 & 71 \\
& Chilpancingo & 20 & 60 \\
\hline
\end{tabular}

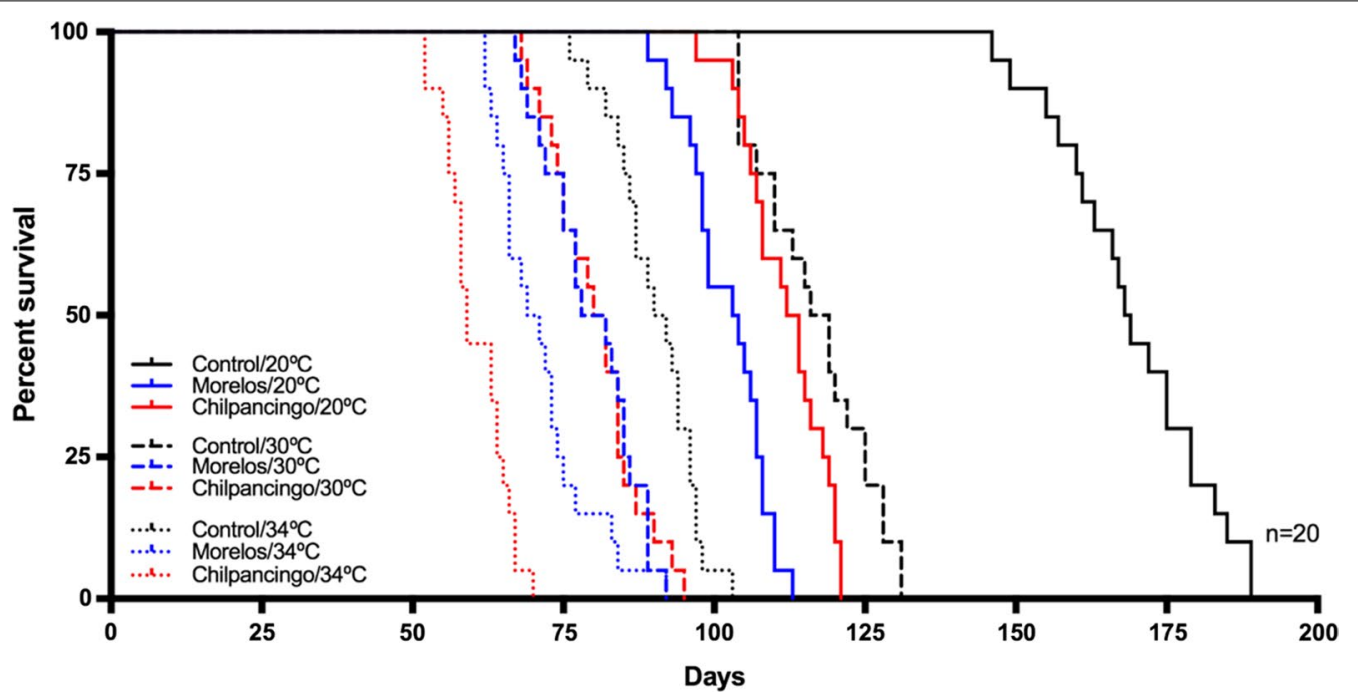

Fig. 9 Survival in infected M. pallidipennis fifth-instar nymphs and control, non-infected nymphs, at different temperatures $\left(20^{\circ} \mathrm{C}, 30^{\circ} \mathrm{C}\right.$ and $\left.34^{\circ} \mathrm{C}\right)$ 


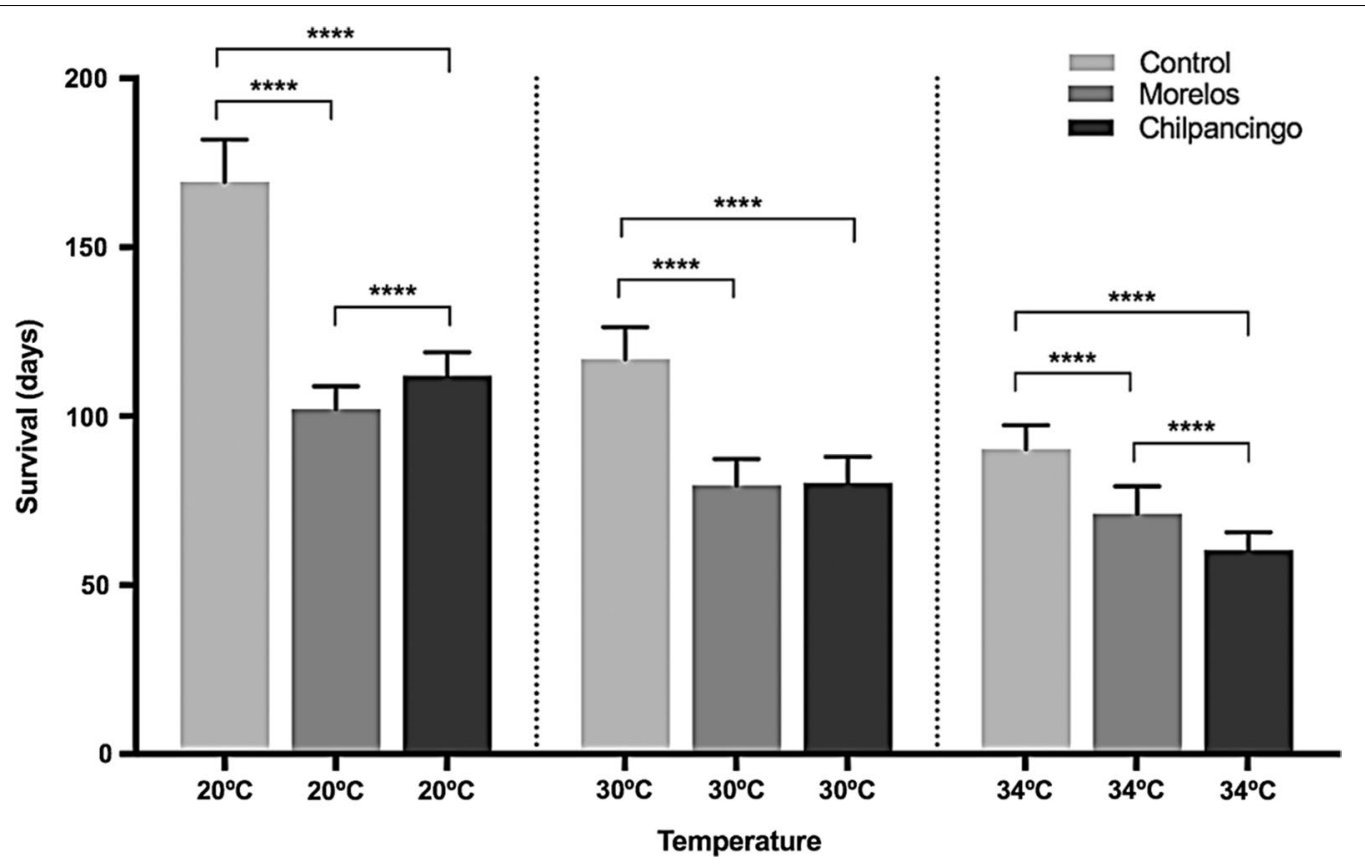

Fig. 10 Survival time in M. pallidipennis fifth-instar nymphs at different temperatures $\left(20^{\circ} \mathrm{C}, 30^{\circ} \mathrm{C}\right.$ and $\left.34^{\circ} \mathrm{C}\right) .{ }^{* * *} \mathrm{P}<0.0001$

Finally, our results have implications for our understanding of the dynamics of Chagas disease in nature. Assuming our experimental scenarios as realistic, the risk of Chagas disease in terms of vector effectivity, measured as triatomine lifespan, would decrease with rising global temperatures. Clearly, this conclusion disregards other complex factors, like the possibility that triatomines modify their feeding behavior as a result of the infection. In this regard, previous studies have reported that infected triatomines feed and defecate more frequently [22] and are more active. Thus, while it can be assumed that infected triatomines live shorter lives, the risk they pose may be unchanged if their feeding rate is higher than that of non-infected insects. If feeding rate is higher, climate change could make vector triatomines as dangerous as today, or even more. Future experiments should determine whether higher temperatures modify the vector capacity of triatomines.

\section{Conclusions}

Our experimental results indicate a covariation between triatomine immune ability and temperature using two $T$. cruzi strains: (i) the prophenoloxidase activity was less robust at temperatures that simulate climate change, and (ii) prophenoloxidase activity was higher in the Chilpancingo than in Morelos strains. Furthermore, triatomine survival was reduced at high temperatures that simulate global change which was more drastic when infected by the Chilpancingo strains. These results imply that climate change scenarios can reduce both triatomine fitness and vector capacity.

\section{Abbreviations}

AMG: anterior midgut; PMG: posterior midgut; proPO: prophenoloxidase; PO: phenoloxidase; DTU: discrete typing unit; U: enzymatic unit.

\section{Acknowledgements}

BG-R thanks Posgrado en Ciencias Biológicas, Universidad Nacional Autónoma de México and Consejo Nacional de Ciencia y Tecnología (CONACYT: 545229) for their support. This paper constitutes a partial fulfillment of the doctoral work of BG-R in the Posgrado en Ciencias Biológicas, Universidad Nacional Autónoma de México. Special thanks to M. O. Vences-Blanco for providing the biological specimens, M. C. de Alba-Alvarado for mouse inoculation, A. L. Flores-Villegas and E. Torres-Gutiérrez for technical support in PO and proPO determination and intestine identification.

\section{Funding}

Financial support was received from the Dirección General de Asuntos del Personal Académico (DGAPA), Programa de Apoyo a Proyectos de Investigación e Innovación Tecnológica (PAPIIT) UNAM, project number IN216118. The Faculty of Medicine (UNAM) provided partial financial support to MC-B, MIB-T and PMS-S.

\section{Availability of data and materials}

The datasets used and/or analyzed during the present study are available from the corresponding author upon request.

\section{Authors' contributions}

$B G-R, M C-B, M I B-T, P M S-S$ and AC-A participated in the design of the study and experiments. BG-R performed the experiments. BG-R and AC-A analyzed the data. MC-B, MIB-T and PMS-S contributed with funding and materials that made the study possible. BG-R, MC-B and AC-A wrote and revised the manuscript. All authors read and approved the final manuscript. 


\section{Ethics approval and consent to participate}

This study was carried out in accordance with the guidelines established by the Norma Oficial Mexicana (NOM-062-ZOO-1999) "Especificaciones técnicas para la producción, cuidado y uso de los animales de laboratorio". Prior to the study, the experimental protocol was evaluated and approved by the Ethics and Research Committee of the Faculty of Medicine from the Universidad Nacional Autónoma de México under project registration no. 014-60314. No human participants were used.

\section{Consent for publication}

No applicable.

\section{Competing interests}

The authors declare that they have no competing interests.

\section{Publisher's Note}

Springer Nature remains neutral with regard to jurisdictional claims in published maps and institutional affiliations.

\begin{abstract}
Author details
${ }^{1}$ Universidad Nacional Autónoma de México, Ciudad de México, Mexico. ${ }^{2}$ Departamento de Microbiología y Parasitología, Facultad de Medicina, Universidad Nacional Autónoma de México, Ciudad de México, Mexico. ${ }^{3}$ Departamento de Ecología Evolutiva, Instituto de Ecología, Universidad Nacional Autónoma de México, Apdo. P. 70-275, Circuito Exterior, Ciudad Universitaria, Coyoacán, 04510 Ciudad de México, Mexico.
\end{abstract}

Received: 30 December 2018 Accepted: 3 May 2019 Published online: 08 May 2019

\section{References}

1. Wolinska J, King KC. Environment can alter selection in host-parasite interactions. Trends Parasitol. 2009;25:236-44.

2. Frainer A, McKie BG, Amundsen PA, Knudsen R, Lafferty KD. Parasitism and the biodiversity-functioning relationship. Trends Ecol Evol. 2018;33:260-8.

3. Campbell-Lendrum D, Manga L, Bagayoko M, Sommerfeld J. Climate change and vector-borne diseases: what are the implications for public health research and policy? Phil Trans R Soc B. 2015;370:20130552.

4. Wu X, Lu Y, Zhou S, Chen L, Xu B. Impact of climate change on human infectious diseases: Empirical evidence and human adaptation. Environ Int. 2016;86:14-23.

5. Cable J, Barber I, Boag B, Ellison AR, Morgan ER, Murray K, et al. Global change, parasite transmission and disease control: lessons from ecology. Philos Trans R Soc Lond B Biol Sci. 2017:372:20160088.

6. World Health Organization. Global technical strategy for malaria 20162030. 2015. https://www.who.int/malaria/areas/global_technical_strat egy/en/. Accessed 20 Nov 2018.

7. Booth M. Climate change and the neglected tropical diseases. Adv Parasitol. 2018;100:39-126.

8. Deutsch CA, Tewksbury JJ, Huey RB, Sheldon KS, Ghalambor CK, Haak DC, Martin PR. Impacts of climate warming on terrestrial ectotherms across latitude. Proc Natl Acad Sci USA. 2008;105:6668-72.

9. Sternberg ED, Thomas MB. Local adaptation to temperature and the implications for vector-borne diseases. Trends Parasitol. 2014;30:115-22.

10. Sgro CM, Terblanche JS, Hoffmann AA. What can plasticity contribute to insect responses to climate change? Annu Rev Entomol. 2016;61:433-51.

11. Yee DA, Ezeakacha NF, Abbott KC. The interactive effects of photoperiod and future climate change may have negative consequences for a widespread invasive insect. Oikos. 2017;126:40-51.

12. Jia $P$, Chen $X$, Chen J, Lu L, Liu Q, Tan X. How does the dengue vector mosquito Aedes albopictus respond to global warming? Parasit Vectors. 2017:10:140.

13. Ogden $\mathrm{NH}$, Lindsay LR. Effects of climate and climate change on vectors and vector-borne diseases: ticks are different. Trends Parasitol. 2016;32:646-56.

14. Chagas C. Nova tripanosomiaze humana: estudos sobre a morfolojia e o ciclo evolutivo do Schizotrypanum cruzi, n. gen, n. sp., ajente etiolojico de nova entidade morbida do homem. Mem Inst Oswaldo Cruz. 1999;1:159-218.

15. Lent H, Wygodzinsky P. Revision of the triatominae (Hemiptera: Reduviidae) and their significance as vectors of Chagas disease. Bull Am Mus Nat Hist. 1979;163:123-520.

16. Moncayo A. Chagas disease: epidemiology and prospects for interruption of transmission in the Americas. World Health Stat Q. 1992;45:276-9.

17. Carcavallo RU, Curto de Casas SI, Sherlock IA, Galíndez Girón I, Jurberg J, Galvao C, Mena Segura CA, Noireau F. Geographic distribution and altilatitudinal dispersion. In: Carcavallo RU, Girón I, Jurberg J, Lent H, editors. Atlas of chagas disease vectors in the Americas. Rio de Janeiro: Fiocruz; 1999. p. 747-92.

18. Piccinali RV, Canale DM, Sandoval AE, Cardinal MV, Jensen O, Kitron U, Gürtler RE. Triatoma infestans bugs in southern Patagonia, Argentina. Emerg Infect Dis. 2010;16:887-9.

19. Di lorio O, Gürtler RE. Seasonality and temperature-dependent flight dispersal of Triatoma infestans (Hemiptera: Reduviidae) and other vectors of Chagas disease in western Argentina. J Med Entomol. 2017:54:1285-92.

20. Fellet MR, Lorenzo MG, Elliot SL, Carrasco D, Guarneri AA. Effects of infection by Trypanosoma cruzi and Trypanosoma rangeli on the reproductive performance of the vector Rhodnius prolixus. PLoS One. 2014;9:e105255.

21. de Fuentes-Vicente JA, Cabrera-Bravo M, Enríquez-Vara JN, Bucio-Torres MI, Gutiérrez-Cabrera AE, Vidal-López DG, et al. Relationships between altitude, triatomine (Triatoma dimidiata) immune response and virulence of Trypanosoma cruzi, the causal agent of Chagas' disease. Med Vet Entomol. 2017;31:63-71.

22. Botto-Mahan C, Cattan PE, Medel R. Chagas disease parasite induces behavioural changes in the kissing bug Mepraia spinolai. Acta Trop. 2006;98:219-23.

23. Martínez-Ibarra JA, Salazar-Schettino PM, Solorio-Cibrián M, CabreraBravo M, Novelo-López M, Vences MO, et al. Influence of temperature and humidity on the biology of Triatoma mexicana (Hemiptera: Reduviidae: Triatominae) under laboratory conditions. Mem Inst Oswaldo Cruz. 2008;103:719-23.

24. Villegas-García JC, Santillán-Alarcón S. The influence of two different temperatures on Meccus pallidipennis Stål, 1872 (Hemiptera: Reduviidae: Triatominae) in laboratory. Entomol Vect. 2004;11:445-56.

25. Catalá S, Gorla D, Basombrio M. Vectorial transmission of Trypanosoma cruzi in an experimental system with susceptible and immunized host. Am J Trop Med Hyg. 1992;47:20-6.

26. Lazzari CR. Temperature preference in Triatoma infestans (Hemiptera: Reduviidae). Bull Em Res. 1991;81:273-6.

27. Asin S, Catalá S. Development of Trypanosoma cruzi in Triatoma infestans: influence of temperature and blood consumption. J Parasitol. 1995;81:1-7.

28. Garza M, Feria Arroyo TP, Casillas EA, Sanchéz-Cordero V, Rivaldi CL, Sarkar S. Projected future distributions of vectors of Trypanosoma cruzi in North America under climate change scenarios. PLoS NegI Trop Dis. 2014;8:e2818.

29. Klotz SA, Dorn PL, Klotz JH, Pinnas JL, Weirauch C, Kurtz JR, Schmidt J. Feeding behavior of triatomines from the southwestern United States: an update on potential risk for transmission of Chagas disease. Acta Trop. 2009;111:114-8.

30. Gürtler RE, Ceballos LA, Ordóñez-Krasnowski P, Lanati LA, Stariolo R, Kitron U. Strong host-feeding preferences of the vector Triatoma infestans modified by vector density: Implications for the epidemiology of Chagas disease. PLoS Negl Trop Dis. 2009;3:e447.

31. Elliot SL, Rodrigues JO, Lorenzo MG, Martins-Filho OA, Guarneri AA. Trypanosoma cruzi, etiological agent of Chagas disease, is virulent to its triatomine vector Rhodnius prolixus in a temperature-dependent manner. PLoS Negl Trop Dis. 2015;9:e0003646.

32. Gage KL, Burkot TR, Eisen RJ, Hayes EB. Climate and vector borne diseases. Am J Prev Med. 2008;35:436-50.

33. Ibarra-Cerdeña CN, Zaldívar-Riverón A, Peterson AT, Sánchez-Cordero V, Ramsey JM. Phylogeny and niche conservatism in North and Central American triatomine bugs (Hemiptera: Reduviidae: Triatominae), vectors of Chagas' disease. PLoS Negl Trop Dis. 2014;8:e3266.

34. Hinestroza G, Ortiz MI, Molina J. Behavioural fever response in Rhodnius prolixus (Reduviidae: Triatominae) to intracoelomic inoculation of Trypanosoma cruzi. Rev Soc Bras Med Trop. 2016;49:425-32. 
35. Barreto-Santana D, Santos-Schuenker L, da Fonseca AR, Gurgel-Gonçalves R, Cuba-Cuba CA. Susceptibility of different Rhodnius species (Hemiptera, Reduviidae, Triatominae) to a Brazilian strain of Trypanosoma rangeli (SC58/KP1-). Biomedica. 2015;35:81-9.

36. Guarneri AA, Lorenzo MG. Triatomine physiology in the context of trypanosome infection. J Insect Physiol. 2017;97:66-76.

37. Kollien AH, Schaub GA. The development of Trypanosoma cruzi in Triatominae. Parasitol Today. 2000;16:381-7.

38. Tyler KM, Engman DM. The life cycle of Trypanosoma cruzi revised. Int J Parasitol. 2001;31:472-81.

39. Garcia ES, Genta FA, Azambuja P, Schaub GA. Interactions between intestinal compounds of triatomines and Trypanosoma cruzi. Trends Parasitol. 2010;26:499-505.

40. Azambuja P, Garcia ES, Waniek PJ, Vieira SC, Figueiredo MB, Gonzalez MS, et al. Rhodnius prolixus: from physiology by Wigglesworth to recent studies of immune system modulation by Trypanosoma cruzi and Trypanosoma rangeli. J Insect Physiol. 2017;97:45-65.

41. Schaub GA, Meiser CK, Balczun C. Interactions of Trypanosoma cruzi and triatomines. In: Mehlhorn H, editor. Progress in parasitology. Berlin: Springer; 2011. p. 155-78.

42. Ferreira RC, Kessler RL, Lorenzo MG, Paim RM, Ferreira Lde L, Probst CM, et al. Colonization of Rhodnius prolixus gut by Trypanosoma cruzi involves an extensive parasite killing. Parasitology. 2016;143:434-43.

43. Daquinag AC, Nakamura S, Takao T, Shimonishi Y. Primary structure of a potent endogenous dopa-containing inhibitor of phenol oxidase from Musca domestica. Proc Natl Acad Sci USA. 1995;92:2964-8.

44. Flores-Villegas AL, Salazar Schettino PM, Córdoba-Aguilar A, GutiérrezCabrera AE, Rojas-Wastavino GE, Bucio-Torres MI, Cabrera-Bravo M. Immune defence mechanisms of triatomines against bacteria, viruses, fungi and parasites. Bull Entomol Res. 2015;105:523-32.

45. Favila-Ruiz G, Jiménez-Cortés JG, Córdoba-Aguilar A, Salazar-Schettino PM, Gutiérrez-Cabrera AE, Pérez-Torres A, et al. Effects of Trypanosoma cruzi on the phenoloxidase and prophenoloxidase activity in the vector Meccus pallidipennis (Hemiptera: Reduviidae). Parasit Vectors. 2018;11:434.

46. Genta FA, Souza RS, Garcia ES, Azambuja P. Phenol oxidases from Rhodnius prolixus: Temporal and tissue expression pattern and regulation by ecdysone. J Insect Physiol. 2010;56:1253-9.

47. Martínez-Ibarra JA, Alejandre-Aguilar R, Torres-Morales A, Trujillo-García JC, Nogueda-Torres B, Trujillo-Contreras F. Biology of three species of the Meccus phyllosomus complex (Hemiptera: Reduviidae Triatominae) fed on blood of hens and rabbits. Mem Inst Oswaldo Cruz. 2006;101:787-94.

48. Vidal-Acosta V, Ibáñez-Bernal S, Martínez-Campo C. Infección natural de chinches Triatominae con Trypanosoma cruzi asociadas a la vivienda humana en México. Salud Publica Mex. 2000;24:496-503.
49. Benítez-Alva Jl, Herón-Huerta, Téllez-Rendón JL. Distribución de triatominos (Heteroptera: Reduviidae) asociados a la vivienda humana y posibles zonas de riesgo en seis estados de la República Mexicana. BIOCYT. 2012;17:327-40.

50. IPCC. 4th Assessment Report "Climate Change 2007: Synthesis Report". 2007. http://www.ipcc.ch/ipccreports/ar4-syr.htm. Accessed 24 Nov 2018.

51. Lee KP, Simpson SJ, Wilson K. Dietary protein-quality influences melanization and immune function in an insect. Funct Ecol. 2008;22:1052-61.

52. Murdock CC, Paaijmans KP, Bell AS, King JG, Hillyer JF, Read AF, Thomas MB. Complex effects of temperature on mosquito immune function. Proc Natl Acad Sci USA. 2012;279:3357-66.

53. Castro DP, Moraes CS, González MS, Ratcliffe NA, Azambuja P, García ES. Trypanosoma cruzi immune response modulation decrease microbiota in Rhodnius prolixus gut and is crucial for parasites survival and development. PLOS ONE. 2012;7:e36591.

54. Laughton AM, Siva-Jothy MT. A standardised protocol for measuring phenoloxidase and prophenoloxidase in the honey bee, Apis mellifera. Apidologie. 2011;42:140-9.

55. Jiménez-Cortés JG, Córdoba-Aguilar A. Condition dependence and trade-offs of sexual versus non-sexual traits in an insect. J Ethology. 2013;31:275-84.

56. Vieira CS, Mattos DP, Waniek PJ, Santangelo JM, Figueiredo MB, Gumiel M, et al. Rhodnius prolixus interaction with Trypanosoma rangeli: modulation of the immune system and microbiota population. Parasit Vectors. 2015:8:135

57. Dang VT, Speck P, Benkendorff K. Influence of elevated temperatures on the immune response of abalone, Haliotis rubra. Fish Shellfish Immunol. 2012;32:732-40.

58. Wojda I. Temperature stress and insect immunity. J Thermal Biol. 2017;68:96-103.

59. Goic B, Stapleford KA, Frangeul L, Doucet AJ, Gausson V, Blanc H, et al. Virus-derived DNA drives mosquito vector tolerance to arboviral infection. Nat Commun. 2016;7:12410.

60. Matetovici I, Caljon G, Van Den Abbeele J. Tsetse fly tolerance to T. brucel infection: transcriptome analysis of trypanosome-associated changes in the tsetse fly salivary gland. BMC Genomics. 2016;17:971.

61. Botto-Mahan C. Trypanosoma cruzi induces life-history trait changes in the wild kissing bug Mepraia spinolai: implications for parasite transmission. Vector-Borne Zoo Dis. 2009;9:505-10.

62. Carmona-Castro O, Moo-Llanes DA, Ramsey JM. Impact of climate change on vector transmission of Trypanosoma cruzi (Chagas, 1909) in North America. Med Vet Entomol. 2018;32:84-101.
Ready to submit your research? Choose BMC and benefit from:

- fast, convenient online submission

- thorough peer review by experienced researchers in your field

- rapid publication on acceptance

- support for research data, including large and complex data types

- gold Open Access which fosters wider collaboration and increased citations

- maximum visibility for your research: over $100 \mathrm{M}$ website views per year

At BMC, research is always in progress.

Learn more biomedcentral.com/submissions 